Article

\title{
Wastewater Treatment by Constructed Wetland Eco-Technology: Influence of Mineral and Plastic Materials as Filter Media and Tropical Ornamental Plants
}

\author{
Sergio Zamora ${ }^{1}{ }^{\circledR}$, J. Luis Marín-Muñíz ${ }^{2}\left(\mathbb{D}\right.$, Carlos Nakase-Rodríguez ${ }^{3}$, \\ Gregorio Fernández-Lambert ${ }^{3}(\mathbb{D})$ and Luis Sandoval ${ }^{3, * \mathbb{D}}$ \\ 1 Faculty of Engineering, construction and Habitat, Universidad Veracruzana Bv. Adolfo Ruíz Cortines 455, \\ Costa Verde, Boca del Rio C.P. 94294, Veracruz, Mexico; szamora@uv.mx \\ 2 Academy of Sustainability and Regional Development, El Colegio de Veracruz, Xalapa 91000 ZC., \\ Veracruz, Mexico; soydrew@hotmail.com \\ 3 Division of Research, Postgraduate Studies and Innovation, Tecnológico Nacional de México/Instituto \\ Tecnológico Superior de Misantla, Misantla C.P. 93821, Veracruz, Mexico; cynakaser@itsm.edu.mx (C.N.-R.); \\ gfernandezl@itsm.edu.mx (G.F.-L.) \\ * Correspondence: lcsandovalh@itsm.edu.mx
}

Received: 15 October 2019; Accepted: 2 November 2019; Published: 8 November 2019

check for updates

\begin{abstract}
Constructed wetlands (CWs) are sustainable technologies where the channels are filled with porous material and plants, which collectively remove pollutants, depending on the type of substrate and vegetation. This study evaluated CWs and their functionality by comparing three ornamental plants (Canna indica, Cyperus papyrus, and Hedychium coronarium) as a phytoremediation process of wastewater, in CWs filled with layers of porous stone-tepezil-plastic residues-soil (S-A), or in microcosms with layers of porous stone-tepezil-soil without the presence of plastic (S-B). The findings during 180 days showed that the removals of pollutants (chemical oxygen demand (COD), total solids suspended (TSS), nitrogen as ammonium $\left(\mathrm{N}-\mathrm{NH}_{4}\right)$, as nitrate $\left(\mathrm{N}-\mathrm{NO}_{3}\right)$, and phosphate $\left(\mathrm{P}-\mathrm{PO}_{4}\right)$ were $20 \%-60 \%$ higher in microcosms with plants than in the absence of plants. Statistical differences were not observed when comparing removal effects among S-A and S-B, indicating that plastic residues as filter material in CWs did not affect the pollutant removal, growth, flowering, and shoots of plants. The use of plastic residues as filter may represent a less costly alternative in CW establishments. Dependence on $\mathrm{N}_{-} \mathrm{NH}_{4}$ and TSS removal was observed according to plant species. The three species used are suitable for using in CWs as wastewater treatment. In addition, the ornamental plants could generate interest for a commercial option.
\end{abstract}

Keywords: eco-technology; phytoremediation; plastic residues; ornamental vegetation; pollutant removal

\section{Introduction}

Constructed wetlands (CWs) are engineered systems that have been designed and constructed to enhance the natural processes for wastewater treatment [1,2]. This CWs system process has been gaining interest and increasing its application in rural and urban areas owing to its low maintenance and operation cost, and high removal of pollutant efficiency by physical, chemical, and biological processes that natural wetlands have, which are also called planet kidneys [3,4].

Comparing the conventional wastewater treatment plant with CWs, the potential environmental impact of CWs is between 2 and 5 times higher, according to lifecycle assessment of a wastewater treatment system [5]. Similarly, the assessment of the sustainability of wastewater treatment systems 
involving environmental, economic, and social dimensions revealed that CWs are the most sustainable amongextended aeration, membrane bioreactor, rotating biological contactor, trickling filter, and sequencing batch reactor systems [6]. Such studies showed the importance of CW technologies.

According to the flow, CWs can be surface-CWs or subsurface-CWs (SSF). These are surface flow CWs when there is only one layer of soil at the bottom of the cell and the wastewater is in contact with the atmosphere, a situation that allows the presence of emergent plants (planted in the ground and projecting from the water column), floating plants on the water column, and/or submerged plants (rooted to the soil but do not protrude from the water column). Subsurface-flow CWs are cells filled with a granular medium of certain porosity that allows the development of microbial films by the presence of the substrate, so they can only have emergent plants [2,7].

The presence of vegetation is one of the most important features of CWs and its presence has several properties (uptake of nutrients, filtering effect, excretion of photosynthesis oxygen, supporting plants, etc.) in relation to the treatment process that makes them an essential component of the design [1]. On the other hand, substrates, also known as media, support matrix/material, filling material, and are one of the major components in CWs. They have been widely acknowledged to play a significant role (as carrier for biofilm development, as medium for plant growth, and as adsorbent for pollutant immobilization) [8]. Typical substrates, such as soil, sand, and gravel, may be confronted with several problems, such as low removal performance and clogging $[9,10]$. While operation and maintenance costs when using CWs are generally low, the conventional media required to form the SSF wetland substrate is typically the single most expensive component $[2,11,12]$.

In this sense, studies about new lower-cost substrates to use as filter material in CWs that are easy to obtain and that do not compromise the processes of pollutant removal efficiency should be carried out.One of these materials may be rough residues of bottles made with polyethylene terephthalate (PET); these rough surfaces can favor the habitat for development of bacterial biofilms that are the main components in the removal of pollutants in CWs. Similarly, residues of building material as tepezyl (inert mineral with fine grain, light weight, and low cost) or the use of porous stone of easy collection in rivers near CWs constructions is also an option.

Thus, the use of materials that are inert and easy to acquire can become an interesting solution in terms of money. In this context, PET bottles, whose destination has increasingly become an environmental liability, requiring recycling and reuse, have the potential to serve as an alternative means of support for subsuperficial CWs. There is little information on the use of plastic residues in constructed wetlands and the affinity with vegetation. In Costa Rica, Central America, a study evaluated PET plastic drinking water bottles as filter media in CWs versus crushed rock with reed beds for treatment of domestic grey water; the planted PET reed beds increased the biomass twice more than that of the planted crushed rock reed beds [13]. Similarly, in China, plastic ring substrate was also evaluated in constructed wetlands for the treated effluent from municipal sewage with water hyacinths, showing an excellent habitat for bacteria that participated in the pollutant abatement processes; the biofilm affinity of the plastic ring substrate with plants favored the abatement efficiency of nitrogen compounds [14]. Both studies revealed the use of plastic as filter media. However, the importance of different pollutant removals and plants with flower production not typical of wetlands is necessary to compare.

Regarding vegetation, Phragmites, Typha, and Scirpus spp. are the most frequently used plants around the world [1]. However, in tropical and subtropical regions, ornamental plants are studied according to their ability of adaptation in $\mathrm{CW}$ conditions. Other investigations have looked at porous river rock or tepezil as media in CWs, showing important removal of pollutants [12,15]. Considering the effect of different substrates as filter media in CWs, the effect of multilayer substrate configuration was evaluated. It was demonstrated that the pollutant removal performance improved in the multilayer (units with three and six layers) compared with the monolayer CWs [16,17].

In this case, the use of waste or local substrates to fill the cells subsurface-flow CWs and the use of ornamental vegetation that generates an aesthetic landscape to produce flowers were investigated. 
In order to know the best design of CWs, and to intensify the removal of pollutants by using ornamental plants with flower production, and different substrates, the main aim of this study was to evaluate the effect of removing pollutants from the community wastewater by using different layers of substrates: porous stone (PRR) + tepezil (TZ) + soil (S-A) vs. PRR + PET + TZ + soil (S-B), and different ornamental vegetation (Cyperus papyrus, Canna indica, and Hedychium coronarium) in subsurface-flow CW microcosms.

\section{Materials and Methods}

This study was conducted in the community of Pastorías (Actopan Township), Veracruz, Mexico $\left(19^{\circ} 33^{\prime} 47.96^{\prime \prime} \mathrm{N}\right.$ and $\left.96^{\circ} 34^{\prime} 18.99^{\prime \prime} \mathrm{W}\right)$. It has 620 inhabitants and has had a sewer system since 2013 [11] (Figure 1). However, there is no system for the treatment of wastewater, and this is only stored in a receiving tank of approximately $15 \mathrm{~m}^{3}$, which is not enough, so wastewater leaves the receiving tank, and gravity flows it into the Topiltepec River, Actopan River sub-basin, causing damage to the flora and fauna of the ecosystem. Furthermore, the use of the river as a recreational area is a common activity in the community, so the wastewater ends up in theriver, which denotes a focus of infection. The climate of the coastal plain of the Gulf of Mexico-a region that includes the community where the microcosms are-has three periods comprising: rainy season from July to October; cold front with strong winds and rain between November and February; and dry periods between March and June [15]. Weather in the region is tropical, with an annual precipitation of $947.1 \mathrm{~mm}$ and an annual average temperature of $24.5^{\circ} \mathrm{C}\left(26.1,26.6,25.2\right.$, and $20.3{ }^{\circ} \mathrm{C}$ in spring, summer, autumn, and winter, respectively).

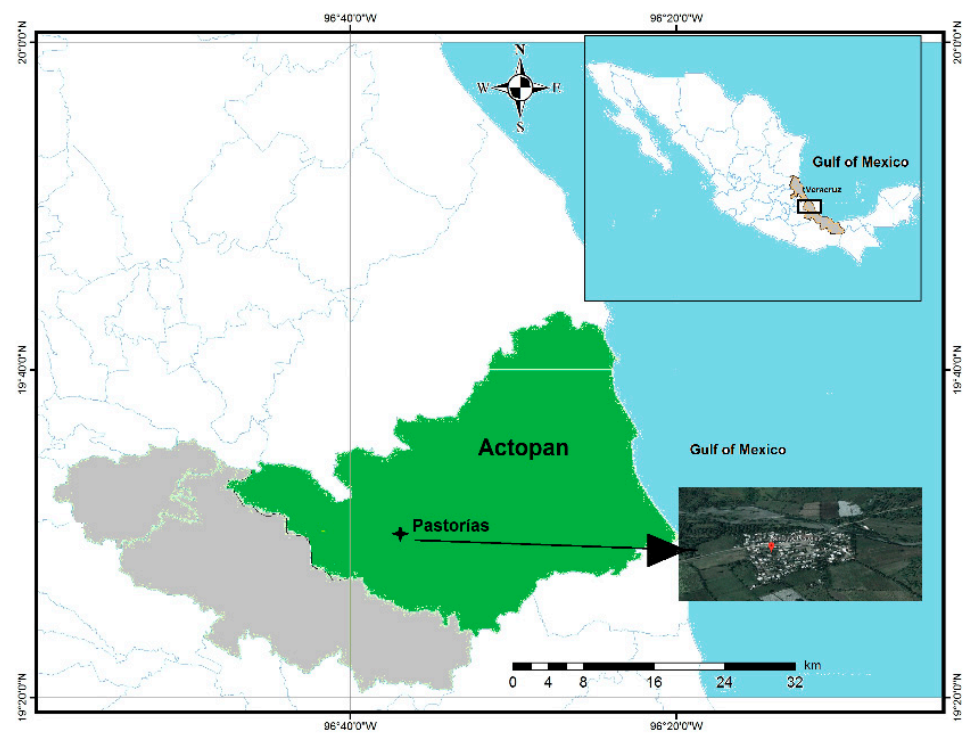

Figure 1. Location of the study site.

\section{Design Features and Operating Criteria of Microcosms}

Sixteen microcosms of horizontal subsurface-flow CWs $(1.1 \mathrm{~m}$ length $\times 0.45 \mathrm{~m}$ width $\times 0.54 \mathrm{~m}$ depth; free-water surface-flow column of $10 \mathrm{~cm} ; 0.109 \mathrm{~m}^{3}$ water volume) were established in a backyard with a transparent roof to avoid the influence of rainwater. Four units were planted with four seedlings of $H$. coronarium, four with C. payrus, four with the same number of plants, but the species was $C$. indica, and four more without plants (Figure 2); cells were half-filled, with a PRR layer $(0.18 \mathrm{~m})$, followed by a layer of TZ (inert mineral such as sand, lightweight, used to make building blocks; $0.17 \mathrm{~m}$ ), and $0.1 \mathrm{~m}$ layer of soil at the bottom (layer called S-A). The other half had PET substituted for $0.17 \mathrm{~m}$ of PRR (as shown in Figure 2) (layer called S-B). Duplicates of experimental units filled in the two different ways by using vegetation, but without the presence of plants, were used as controls or white units. PRR was collected from the Topiltepec river (50\% porosity; (diameter below which $10 \%$ of the substrate remains, by weight) $\mathrm{D}_{10}=0.04$, (diameter below which $60 \%$ of the substrate remains, by weight) 
$\mathrm{D}_{60}=0.05$, uniformity coefficient $(\mathrm{CU})=1.25$, average diameter $\left.=0.025 \mathrm{~m}\right)$. TZ was collected as waste in a community building $\left(40 \%\right.$ porosity; $\mathrm{D}_{10}=0.03, \mathrm{D}_{60}=0.04, \mathrm{CU}=1.33$, average diameter $=$ $0.028 \mathrm{~m}$ ). Plastic residues were bottle necks, plastic bottle caps, and the rough base of bottles. Substrates were approximately $2.5 \mathrm{~cm}$ in diameter. Mineral material was washed before the use in the CWs. Experimental units were fed tap water for 30 days, followed by10 days with wastewater mixed with $50 \%$ tap water for the process of vegetation adaptation. Subsequently, the fed water was wastewater from a manifold of $1100 \mathrm{~L}$, which was filled by pumping from the drainage system. A plastic mesh was previously put at the end of the hose in order to trap large suspended solids (primary treatment). Experimental units were operated at a hydraulic retention time of three days, inflow rate (HRT): $0.04 \mathrm{~m}^{3} /$ day, and hydraulic loading rate of $8.0 \mathrm{~cm} /$ day. It is also worth mentioning that the three species of plants used were chosen because of their abundant presence in the region.

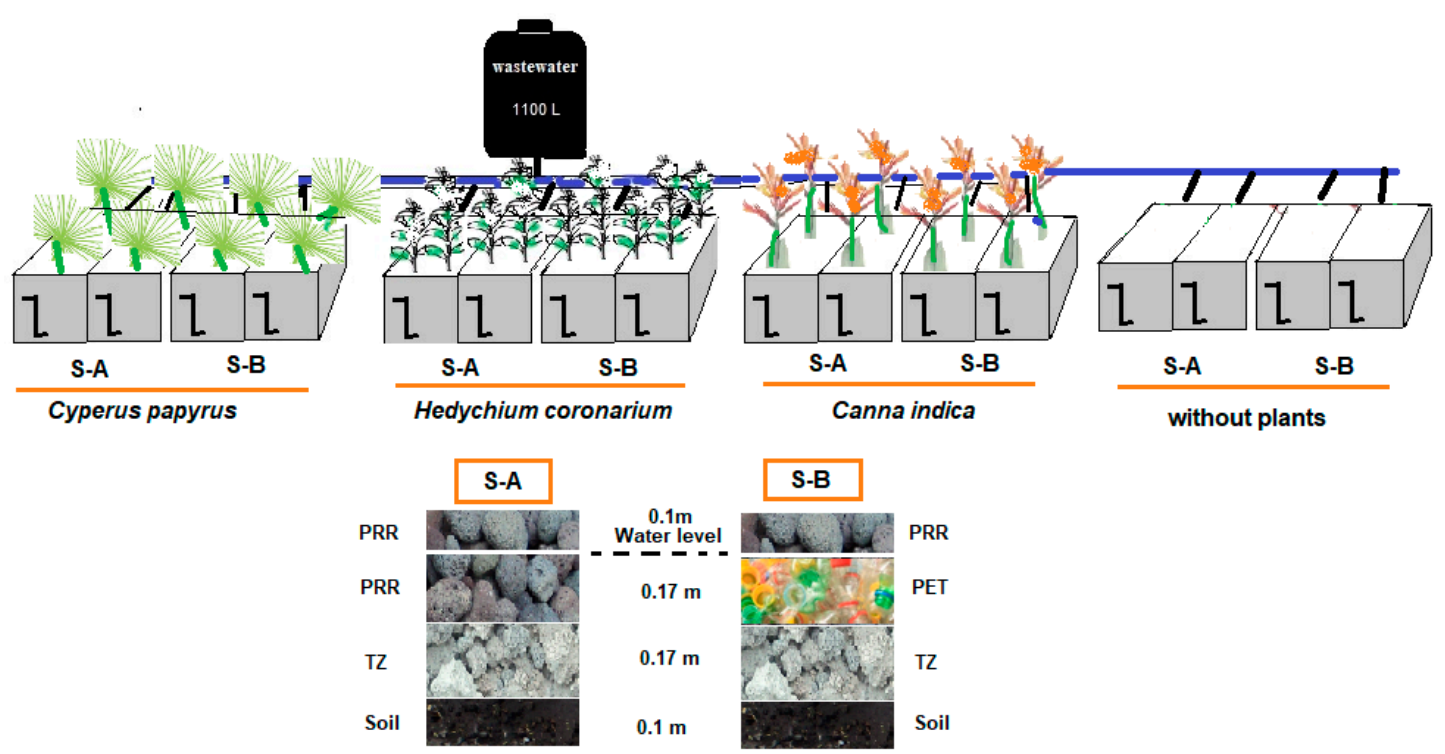

Figure 2. Schematic of the microcosms wetland study and materials used as filter media in the constructed wetlands $(\mathrm{CWs})$ in this study. PRR = porous stone, $\mathrm{TZ}=$ tepezyl, $\mathrm{PET}=$ plastic residues, S-A = layer with PRR + PRR + TZ + soil, S-B = layer with PRR + PET + TZ + soil.

The parameters measured as indicators of water quality were chemical oxygen demand (COD), total solids suspended (TSS), nitrogen as nitrates $\left(\mathrm{N}-\mathrm{NO}_{3}\right)$, and ammonium $\left(\mathrm{N}-\mathrm{NH}_{4}\right)$, and phosphate $\left(\mathrm{P}-\mathrm{PO}_{4}\right)$, and dissolved oxygen (DO), measured according to standard methods [18]. The percentage of contaminant removals (Em) was determined by the Equation (1) [11-13].

$$
\mathrm{Em}=[(\mathrm{Ci}-\mathrm{Ce}) / \mathrm{Ci}] \times 100 \%
$$

where $\mathrm{Ci}$ is the concentration of the pollutant in the influent $(\mathrm{mg} / \mathrm{L})$, and $\mathrm{Ce}$ is the concentration of the pollutant in the effluent $(\mathrm{mg} / \mathrm{L})$.

For plant growth, individual plant height and the stem diameter were measured every 15 days using a measuring tape and a digital Vernier caliper (Mod. 405146, OBI GmbH \& Co., Wermelskirchen, Germany), respectively. Root length and root volume (RV) were determined at the end of the study. The RV was measured by water volume displacement [19].

All statistical analyses were performed using SPSS 22 for windows XP. (Inc., Chicago, IL, USA). One/two-way ANOVA was used to detect differences among removal pollutants according to the ornamental plants and support material. One-way ANOVA was used to compare differences in plant growth measurements. For all tests, a significance level of $p<0.05$ was applied. 


\section{Results}

Data of $\mathrm{pH}, \mathrm{DO}$ and temperature of wastewater in the inflow and outflow of microcosms are reported in Table 1; three pieces of data are important for removal processes. The $\mathrm{pH}$ in water ranged from 7.0 to 7.4 in the experimental units, with an average value of $7.6 \pm 0.3$ at the inflow, an optimal $\mathrm{pH}$ (6.5-8.5) for nitrogen transformations [20]. The DO was $2.2 \pm 0.3 \mathrm{mg} / \mathrm{L}$ at inflow, while at the outflow, the concentrations were between 4.5 and 5.1 for systems with presence of vegetation, and between 2.5 and $2.6 \mathrm{mg} / \mathrm{L}$ in systems without presence of plants. The water temperature was similar in both the inflow and the outflow of the experimental units $\left(18-20^{\circ} \mathrm{C}\right)$. Many individual wetland processes, such as microbial mediated reactions, are affected by temperature; optimal conditions for plant growth and microbial organisms are between 19 and $34{ }^{\circ} \mathrm{C}[3,21]$.

Table 1. $\mathrm{pH}$, dissolved oxygen (DO), and water temperature. Mean values \pm standard error $(n=156)$.

\begin{tabular}{cccccccccc}
\hline \multirow{2}{*}{$\begin{array}{c}\text { Parameter/ } \\
\text { Microcosms }\end{array}$} & Influent & \multicolumn{2}{c}{ C. papyrus } & \multicolumn{2}{c}{ C. indica } & \multicolumn{2}{c}{ H. coronarium } & \multicolumn{2}{c}{ Control } \\
\cline { 2 - 10 } & & S-A & S-B & S-A & S-B & S-A & S-B & S-A & S-B \\
\hline $\mathrm{pH}(\mathrm{pH}$ units) & $7.6 \pm 0.3$ & $7.5 \pm 0.9$ & $7.4 \pm 0.6$ & $7.3 \pm 0.6$ & $7.5 \pm 0.2$ & $7.1 \pm 0.9$ & $7.0 \pm 0.7$ & $7.4 \pm 0.2$ & $7.4 \pm 0.1$ \\
\hline $\mathrm{DO}\left(\mathrm{mg} \mathrm{L}^{-1}\right)$ & $2.2 \pm 0.3$ & $5.1 \pm 0.9$ & $4.9 \pm 0.8$ & $4.8 \pm 0.7$ & $5.2 \pm 0.7$ & $4.7 \pm 1.1$ & $4.5 \pm 0.5$ & $2.6 \pm 0.5$ & $2.5 \pm 0.4$ \\
\hline Temperature & $18.0 \pm$ & $18.6 \pm$ & $18.1 \pm$ & $18.5 \pm$ & $18.6 \pm$ & $17.8 \pm$ & $18.2 \pm$ & $20.0 \pm$ & $19.9 \pm$ \\
$\left({ }^{\circ} \mathrm{C}\right)$ & 0.9 & 0.2 & 1.3 & 0.6 & 0.8 & 1.6 & 0.7 & 0.6 & 0.7 \\
\hline
\end{tabular}

According to the growth of the species evaluated (Table 2), statically differences were not observed among S-A and S-B $(p>0.05)$. Differences were revealed with respect to plant species. C. indica tended to have higher maximum height $(59-62 \mathrm{~cm})$, root volume $\left(408-424 \mathrm{~cm}^{3}\right)$, root length $(10-43 \mathrm{~cm})$, and flower (7-8) and shoot production (5 in S-A and S-B), followed by C. papyrus and H. coronarium. This last specie never produced flowers during the study. The better growth characteristics for Canna are derivative of nature of the species and easy adaptation to wetland conditions reported in other studies [22]. For H. coronarium, also called matandrea, white or ginger butterfly, depending on the region, reproduction is important because several of its components such as rhizomes or leaves have been reported to be beneficial against infections and joint pain, probably more time in $\mathrm{CW}$ conditions are necessary for flower production [23].

This species shows adaptation to wastewater treatment systems, leading to the consideration of it as an attractive option in this type of eco-technology, due to its flowering and the additional use of the flower for seedling production, or use of its components for medicinal or handcraft aspects. Considering these advantages, plus the ability to function as phytoremediation, they are now a viable option in CWs systems. The use of plastic residues is also an option that allows its reuse, avoiding garbage accumulation. In mangrove ecosystems, the detection of plastic residues was almost $63 \%$ higher compared with wood, explained by local activities and wastewater discharges [24]. The use of the plastic residues as filter media in CWs is an option to avoid plastic residues in coastal ecosystems and oceans, where various species could be affected. 
Table 2. Growth characteristics of vegetation.

\begin{tabular}{|c|c|c|c|c|c|c|c|}
\hline $\begin{array}{c}\text { Ornamental } \\
\text { Plant }\end{array}$ & $\begin{array}{c}\text { Material } \\
\text { Layer }\end{array}$ & $\begin{array}{l}\text { Maximum } \\
\text { Root Length } \\
(\mathrm{cm})\end{array}$ & $\begin{array}{l}\text { Maximum } \\
\text { Root Volume } \\
\left(\mathrm{cm}^{3}\right)\end{array}$ & $\begin{array}{l}\text { Maximum } \\
\text { Plant } \\
\text { Height }(\mathrm{cm})\end{array}$ & $\begin{array}{l}\text { Number } \\
\text { of Flower } \\
\text { Production }\end{array}$ & $\begin{array}{l}\text { Number } \\
\text { of Shoots }\end{array}$ & Plant Health \\
\hline \multirow{2}{*}{ C. indica } & S-A & $42.3 \pm 11.6^{a}$ & $424 \pm 29.6^{a}$ & $59.2 \pm 16.2^{\mathrm{a}}$ & $8^{\text {a }}$ & $5^{\mathrm{a}}$ & $\begin{array}{l}\text { Without wilting } \\
\text { or pests }\end{array}$ \\
\hline & S-B & $40.6 \pm 12.0^{\mathrm{a}}$ & $408 \pm 19.2^{\mathrm{a}}$ & $61.8 \pm 15.9^{a}$ & $7^{\mathrm{a}}$ & $5^{\mathrm{a}}$ & $\begin{array}{l}\text { Without wilting } \\
\text { or pests }\end{array}$ \\
\hline \multirow{2}{*}{ H. coronarium } & S-A & $14.4 \pm 2.6^{c}$ & $60 \pm 11.0^{c}$ & $40.8 \pm 3.2^{b}$ & $0^{c}$ & $1^{c}$ & $\begin{array}{l}\text { Without wilting } \\
\text { or pests }\end{array}$ \\
\hline & S-B & $19.0 \pm 6.9^{c}$ & $56 \pm 11.1^{c}$ & $43.0 \pm 6.3^{b}$ & $0^{c}$ & $0^{c}$ & $\begin{array}{l}\text { Without wilting } \\
\text { or pests }\end{array}$ \\
\hline \multirow{2}{*}{ C. papyrus } & S-A & $28.6 \pm 9.4^{b}$ & $106 \pm 28.2^{b}$ & $30.3 \pm 6.7^{b}$ & $4^{b}$ & $4^{\mathrm{b}}$ & $\begin{array}{l}\text { Without wilting } \\
\text { or pests }\end{array}$ \\
\hline & S-B & $30.2 \pm 9.1^{b}$ & $99 \pm 16.4^{b}$ & $30.0 \pm 5.7^{b}$ & $4^{b}$ & $4^{b}$ & $\begin{array}{c}\text { Without wilting } \\
\text { or pests }\end{array}$ \\
\hline
\end{tabular}

Values are given as the average \pm standard error. Within each column, numbers with the same letter are not significantly different $(p>0.05)$ from each other. Data with letter " $a$ " superscript are is higher value than data with "b" or "c".

\section{Concentration and Removal of Pollutants in CW Microcosms}

In the system input, the average concentration of organic matter was measured as COD ( $408 \pm 49 \mathrm{mg} / \mathrm{L}$ ), while the outputs ranged from 33 to $96 \mathrm{mg} / \mathrm{L}$ (Table 3). The influent concentrations oscillated among 30-480 mg/L (Figure 3). Low observed concentrations indicated removal of such as a parameter in a range of $76 \%$ to $78 \%$ in control systems, while in the mesocosms with plants, the removal fluctuated between $90 \%$ and $92 \%$, regardless of the type of species $(p=0.088)$ or layer of materials $(p=0.091)$. COD reduction in microcosms with vegetation compared with controls (almost $15 \% ; p<0.05$ ) alluded to the root exudation and oxygen supply provided by plants through their parenchymal system, which favors the development of a microbial community responsible for the process of removal of the organic matter $[25,26]$. Likewise, it has been reported that plant roots minimize water velocity, and thus promote sedimentation of suspended organic matter [1,24]. According to CONAGUA, in Mexico, the water bodies monitors have established that an acceptable criterion of COD discharges in wastewater that is biologically treated must not exceed $40 \mathrm{mg} / \mathrm{L}$ [27]. Our values are under this criterion, indicating the importance of the technology with the ornamental plants used for COD removal.

TSS is a necessary water quality parameter because of its adverse effects on aquatic species and wildlife. Russell [28] indicates that water with acceptable quality must be between 76 and $150 \mathrm{mg} / \mathrm{L}$, good quality between 26 and $75 \mathrm{mg} / \mathrm{L}$, and excellent quality with concentrations $\leq 25 \mathrm{mg} / \mathrm{L}$. In this study, the inlet concentration was $766 \pm 85 \mathrm{mg} / \mathrm{L}$ ( $80-870 \mathrm{mg} / \mathrm{L}$; Figure 3), which was reduced when passing through the CW technology (498-504 mg/L in control units and 179-364 mg/L in microcosms with plants), reflected, in turn, in the removals (Table 3). Note that these were statistically higher $(p>0.05)$ in the presence of vegetation microcosms regardless of the difference in substrate layers $(52 \%-77 \%)$, compared with experimental units with no plants $(34 \%-35 \%)$. One effect of plant species was detected, $H$. coronarium microcosms revealed less removal of TSS $(52 \%-57 \% ; p \leq 0.05)$ versus other plant species $(73 \%-77 \%)$, probably related with the less root production compared with the root volume production of Canna and Cyperus species; the root has a role as filter, contributing in the adsorption of solids. The detected data indicates that the treated water still had high concentrations of TSS, despite removals of almost $80 \%$, which is a significant level of removal within environmental eco-technology. A hybrid CW system could be implemented for a better removal of TSS, as indicate other authors $[29,30]$. 


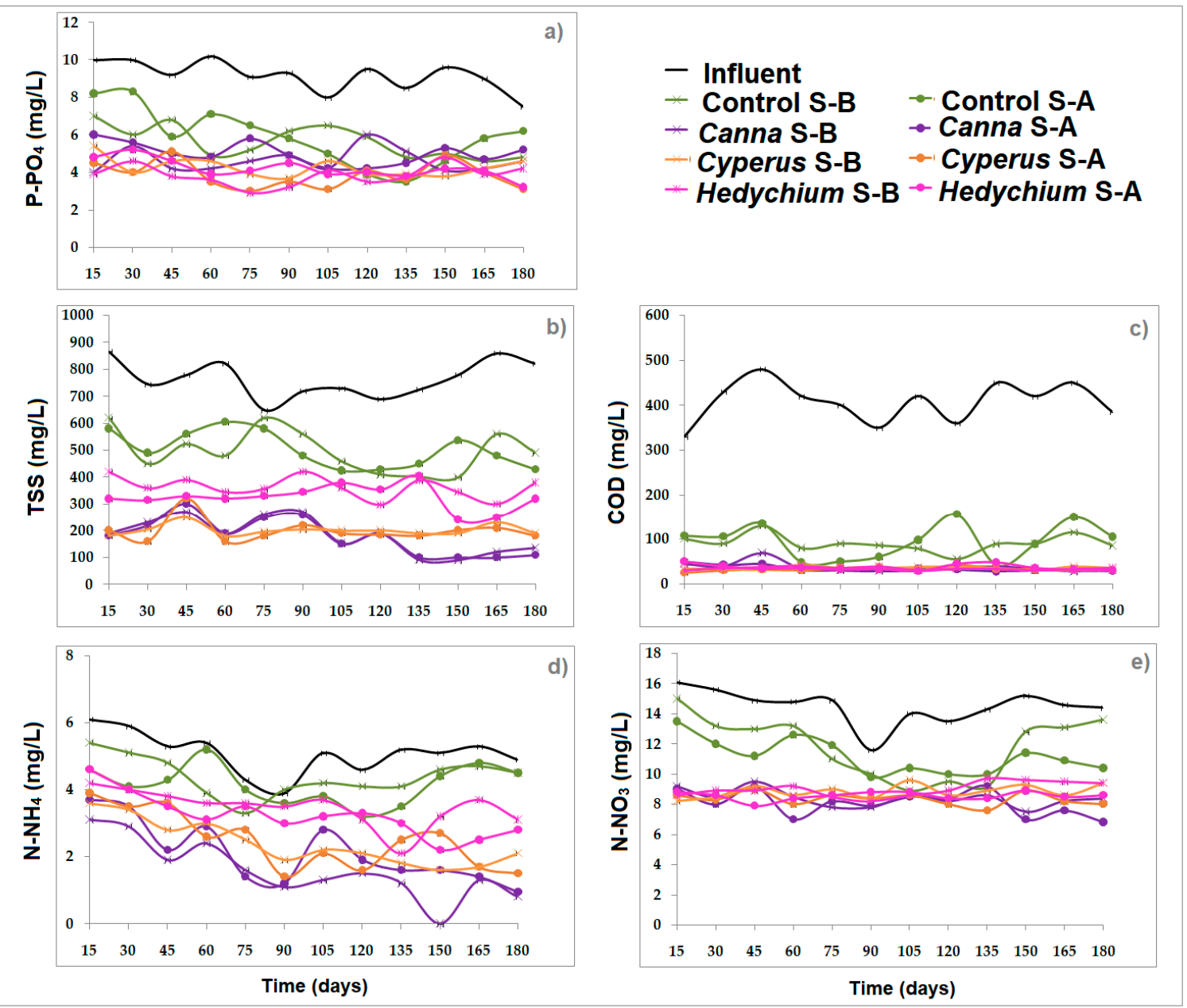

Figure 3. Phosphate (a), total solids suspended (b), chemical oxygen demand (c), ammonium (d), and nitrogen as nitrates (e) concentrations at the inflow and outflow of constructed wetland microcosms.

The average concentration of $\mathrm{N}^{-\mathrm{NO}_{3}}$ at the inflow was $14.4 \pm 1.6 \mathrm{mg} / \mathrm{L}(7-16 \mathrm{mg} / \mathrm{L}$; Figure 3), while in the microcosms ranged from 8.1 to $11.9 \mathrm{mg} / \mathrm{L}$, which meant removals of $17 \%$ to $21 \%$ in control systems, and $37 \%$ to $44 \%$ in microcosms with vegetation (Table 3). CW technology systems with different ornamental plants and material layers showed no significant difference $(p=0.198)$. This indicated that the presence of vegetation favored the release of radial oxygen [25], and this allowed nitrification in the rhizosphere zone. After denitrification processes in the anaerobic area, this last process could only have been present in the microcosms without plant species, and in less magnitude, since the presence of plants under anaerobic conditions also favors carbon exudation from the root, which intensifies the denitrification processes [31]. Based on data from the US Environmental Protection Agency (USEPA) [32], the maximum allowed limit of $\mathrm{N}^{-N_{3}}$ to allow aquatic life in freshwater systems acutely should not exceed $3.0 \mathrm{mg} / \mathrm{L}$ and $10 \mathrm{mg} / \mathrm{L}$ for recreational and aesthetic bodies of water, respectively. Besides that, when it is used for recreational uses and obtaining fish for consumption, it is a priority to lower levels of the ion, which even with the treatment of wetlands higher than $3.0 \mathrm{mg} / \mathrm{L}$, could be mitigated by combining superficial wetland systems and subsurface CWs of both horizontal and vertical flow. In this study, in presence of vegetation, the results obtained are under the $10 \mathrm{mg} / \mathrm{L}$, indicating that CWs are a good option for nitrate removals, however, other considerations (most HRT, hybrid system) could be studied for decrease of nitrate concentrations.

Concentrations of $\mathrm{P}_{-} \mathrm{PO}_{4}$ oscillated among 3.5-10 mg/L (Figure 3). The average amount of $\mathrm{P}^{-} \mathrm{PO}_{4}$ present at the input of the microcosms was $9.11 \pm 1.4 \mathrm{mg} / \mathrm{L}$, while in effluents, varied with respect to the presence of plants, reflected in the different removals of the compound (Table 3). Ion removals 
tended to be statistically higher $(p>0.05)$ in the systems with vegetation $(45 \%-57 \%)$. Regardless of the type of material layer, this is because the roots of plants provided a significant area of ion adsorption $[2,25,26]$. It can be noted that the detected ion concentration exceeded the limits set by the USEPA [32], which establishes a maximum of $0.05 \mathrm{mg} / \mathrm{L}$ ion in water bodies to prevent eutrophication problems. Although removals in the presence of vegetation were above $60 \%$, these waters still require more treatment to reduce the toxic effects if this wastewater was discharged to other bodies of water, which can be solved by adding the surface wetlands or stabilizing gaps for hybrid wetlands with higher rates of removal. Several environmental factors influence the phosphorous removal in CWs. Added to the adsorption, plant uptake of phosphorous is another mechanism of removal, and this is related with the higher removals of the ion compared with the units without plants [2,3,11]. The use of calcium inside matrix-filled material is an option to implement, because, according to Wang et al. [33], calcium stimulates the chemisorptions as an adsorption mechanism and obtains a high efficiency of phosphorous removal filler in CWs. Another studied option for adsorption, desorption, and regeneration of phosphate is using pyrolyzed biochars from wood, corncobs, rice husks, and sawdust. For all biochars, the sorption process was reversible and the adsorbed phosphate could be desorbed in both neutral and acid solution environments, revealing that implied biochar could be effectively used to recover phosphate from anaerobic digestate [34].

In the case of ammonium, the concentrations were between 0 and $6 \mathrm{mg} / \mathrm{L}$ (Figure 3), an average concentration of $5.09 \pm 1.0 \mathrm{mg} / \mathrm{L}$ was observed, while a range of ion concentrations in the outputs of 1.6 to 4.6 were observed (Table 3). The $\mathrm{N}-\mathrm{NH}_{4}$ was the most poorly removed in control systems $(<21 \%)$, as expected, since this form of nitrogen is preferably absorbed by vegetation, and whereas in the mesocosms control with no plants, this was only used by the microbial presence for nitrification. In units with plants, the removal was greater than that of the controls, and differences between systems with different species planted were observed $(p=0.036)$; in systems with $C$. indica, the removal was greater than $62 \%$, both in presence and in absence of plastic residues in the material layers, whereas in cells with the presence of $C$. papyrus, ion removals did not exceed $55 \%$. For $H$. coronarium, the removal percentage observed was among $31 \%$ and $39 \%$. The above was also reflected in the height and root characteristics of species (Table 1). To see if this ion is within permissible limits, since in Mexico this parameter is not regulated, it was compared with data from the Taiwan Environmental Protection Agency, where they report that only $0.5 \mathrm{mg} / \mathrm{L}$ of the ion are permissible for protection of aquatic life [35], so more polishing is still required of wastewater by using only the treatment system of this study. The polyculture evaluation should be an option to increase the ammonium removal by comparing monoculture versus polyculture of plants in pollutant removal efficiency [36,37].

It is worth describing that microbial degradation is an important pathway during removal of pollutants in CWs. Some authors $[14,16,38]$ have revealed that the microbial activity and metabolic richness in the interstitial water and biofilm in CWs are influenced by CW design, vegetation, and filter material. In this study, the microbial film was not analyzed, but it is recommended to analyze it along with design parameters. On the other hand, regarding the use of plastic residues as filter media, water and atmospheric transport pathway investigations are necessary. Studying the occurrence, fate, and behavior of atmospheric microplastics in remote areas may provide insight and understanding regarding the extent of microplastic pollution as well as the historical trends recorded in ice cores. Such studies are very few in number, and significant effort will be needed to extend this avenue of research [39]. Furthermore, increasing attention and studies on water and atmospheric microplastic pollution would be particularly beneficial to the protection of ecosystems. 
Table 3. Average concentrations and removals of contaminants removed in the mesocosms CWs.

\begin{tabular}{|c|c|c|c|c|c|c|c|c|}
\hline \multirow{3}{*}{ Parameter } & \multicolumn{8}{|c|}{ Wetland Vegetation in Different Substrates } \\
\hline & \multicolumn{2}{|c|}{ Canna indica } & \multicolumn{2}{|c|}{ Cyperus papyrus } & \multicolumn{2}{|c|}{ Hedychium coronarium } & \multicolumn{2}{|c|}{ Control } \\
\hline & S-A & S-B & S-A & S-B & S-A & S-B & S-A & S-B \\
\hline \multicolumn{9}{|l|}{ COD } \\
\hline EC & \multicolumn{8}{|c|}{$408 \pm 49$} \\
\hline CS & $35 \pm 13$ & $37 \pm 11$ & $33 \pm 14$ & $36 \pm 14$ & $37 \pm 9.6$ & $35 \pm 14$ & $96 \pm 11$ & $91 \pm 7.4$ \\
\hline Removal (\%) & $91.4 \pm 16^{\mathrm{a}}$ & $90.9 \pm 09^{a}$ & $91.9 \pm 11^{\mathrm{a}}$ & $91.2 \pm 13^{\mathrm{a}}$ & $90.9 \pm 14.3^{\mathrm{a}}$ & $91.4 \pm 10.2^{\mathrm{a}}$ & $76.5 \pm 14.4^{b}$ & $77.7 \pm 11.2^{b}$ \\
\hline \multicolumn{9}{|l|}{ TSS } \\
\hline $\mathrm{EC}$ & & & \multicolumn{6}{|c|}{$766 \pm 85$} \\
\hline CS & $179 \pm 18$ & $182 \pm 28$ & $198 \pm 32$ & $201 \pm 25$ & $326 \pm 56$ & $364 \pm 49$ & $504 \pm 61$ & $498 \pm 69$ \\
\hline Removal (\%) & $76.7 \pm 12^{a}$ & $76.2 \pm 17^{\mathrm{a}}$ & $74.2 \pm 11.2^{a}$ & $73.8 \pm 29^{a}$ & $57.4 \pm 11^{\mathrm{b}}$ & $52.5 \pm 16^{\mathrm{b}}$ & $34.2 \pm 12^{c}$ & $35.1 \pm 08^{c}$ \\
\hline \multicolumn{9}{|l|}{$\mathrm{N}-\mathrm{NO}_{3}$} \\
\hline EC & & & \multicolumn{6}{|c|}{$14.4 \pm 1.6$} \\
\hline CS & $8.1 \pm 1.2$ & $8.5 \pm 1.4$ & $8.4 \pm 0.72$ & $8.9 \pm 0.22$ & $8.6 \pm 0.95$ & $9.0 \pm 0.98$ & $11.1 \pm 0.13$ & $11.9 \pm 1.0$ \\
\hline Removal (\%) & $44 \pm 6.8^{\mathrm{a}}$ & $41.0 \pm 4.2^{\mathrm{a}}$ & $41.7 \pm 8.8^{a}$ & $38.2 \pm 9.6^{\mathrm{a}}$ & $40.3 \pm 11.6^{a}$ & $37.5 \pm 5.0^{a}$ & $20.8 \pm 7.6^{\mathrm{b}}$ & $17.4 \pm 4.3^{b}$ \\
\hline \multicolumn{9}{|l|}{$\mathrm{P}-\mathrm{PO}_{4}$} \\
\hline $\mathrm{EC}^{\mathrm{T}}$ & & & \multicolumn{6}{|c|}{$9.11 \pm 1.4$} \\
\hline $\mathrm{CS}$ & $5.0 \pm 0.6$ & $4.6 \pm 9.2$ & $3.9 \pm 0.2$ & $4.2 \pm 0.7$ & $4.1 \pm 0.6$ & $3.9 \pm 0.16$ & $5.9 \pm 1.0$ & $5.6 \pm 0.8$ \\
\hline Removal (\%) & $45.1 \pm 6.1^{\mathrm{a}}$ & $49.5 \pm 4.9^{\mathrm{a}}$ & $57.2 \pm 9.9^{a}$ & $53.9 \pm 8.9^{a}$ & $55.0 \pm 3.1^{\mathrm{a}}$ & $57.2 \pm 2.6^{\mathrm{a}}$ & $35.2 \pm 0.8^{b}$ & $38.5 \pm 2.1^{b}$ \\
\hline \multicolumn{9}{|l|}{$\mathrm{N}-\mathrm{NH}_{4}$} \\
\hline EC & & & \multicolumn{6}{|c|}{$5.09 \pm 1.0$} \\
\hline CS & $1.9 \pm 0.7$ & $1.6 \pm 0.8$ & $2.5 \pm 0.5$ & $2.3 \pm 0.4$ & $3.1 \pm 0.14$ & $3.5 \pm 0.9$ & $4.2 \pm 1.2$ & $4.6 \pm 0.9$ \\
\hline Removal (\%) & $62.7 \pm 4.2^{\mathrm{a}}$ & $68.6 \pm 0.8^{a}$ & $50.9 \pm 5.2^{b}$ & $54.8 \pm 3.6^{b}$ & $39.1 \pm 4.6^{c}$ & $31.2 \pm 8.1^{\mathrm{c}}$ & $17.5 \pm 1.6^{\mathrm{d}}$ & $20.2 \pm 1.2^{\mathrm{d}}$ \\
\hline
\end{tabular}

Values are given as the average \pm standard error. Different letters (superscript) indicate significant differences between the rows at the $5 \%$ significance level. Data with letter "a" superscript are is higher value than data with " $\mathrm{b}$ ", "c" or " $\mathrm{d}$ ". 


\section{Conclusions}

Using constructed wetlands with ornamental plants and filled with mineral and plastic residues to remove contaminants from wastewater is a sustainable option. The use of Canna indica, Hedychium coronarium, and Cyperus payrus revealed easy adaptation and growth without wilting and pests under $\mathrm{CW}$ conditions. According to the study, it was also found that adding plastic residues as a layer along with PRR and TZ as filter materials in microcosms does not change the effect of growth of plants and removal of pollutants, indicating the importance of reusing plastic residues as filter material support. Differences among plant species revealed influence on pollutant removal. C. indica had better ammonia and TSS removals than other species; however, all three plants used were able to remove more contaminants than experimental units without plants. CWs systems with ornamental vegetation are an option that could favor their use at home, as floral gardens and to avoid public health problems. Therefore, it is suggested to apply these sustainable alternatives in areas without conventional treatment plants of wastewater and to consider the use of the plants and material evaluated in future CW design.

Author Contributions: Conceptualization, J.L.M.-M.; Methodology, J.L.M.-M. and L.S.; Validation, J.L.M.-M., S.Z. and G.F.-L.; Formal analysis, J.L.M.-M. and L.S.; Investigation, J.L.M.-M., S.Z., G.F.-L. and C.N.-R.; Resources, J.L.M.-M. and C.N.-R.; Data curation, J.L.M.-M. and L.S.; Writing-original draft preparation, J.L.M.-M. and L.S.; Writing-review and editing, J.L.M.-M. and L.S.; Visualization, J.L.M.-M., S.Z. and G.F.-L.; Supervision, J.L.M.-M.; Project administration, J.L.M.-M. and C.N.-R.; Funding acquisition, L.S., S.Z., G.F.-L., and C.N.-R.

Funding: This research received no external funding.

Acknowledgments: The authors acknowledge to El Colegio de Veracruz, Tecnológico Nacional de México, and Universidad Veracruzana for the permits to carry out the study.

Conflicts of Interest: The authors declare no conflict of interest.

\section{References}

1. Vymazal, J. Plants used in constructed wetlands with horizontal subsurface flow: A review. Hydrobiologia 2011, 674, 133-156. [CrossRef]

2. Vidal, G.; Hormazábal, S. Constructed Wetland Operation and Design, 1st ed.; Universidad de Concepción: Concepción, Chile, 2018; ISBN 978-956-227-419-7. (In Spanish)

3. Mitsch, W.J.; Gosselink, J. Wetlands; John Wiley and Sons Inc.: New York, NY, USA, 2015; Volume 5, p. 456.

4. Marín-Muñiz, J.L. Humedales, Riñones del Planeta y Hábitat de Múltiples Especies; Editora de Gobierno del Estado de Veracruz: Xalapa, Veracruz, Mexico, 2018; (In Spanish). Available online: https://www.sev.gob.mx/ servicios/publicaciones/serie_fueraseries/Humedales_Impresion.pdf (accessed on 5 November 2019).

5. Garfí, M.; Flores, L.; Ferrer, I. Life cycle assessment of wastewater treatment system for small communities: Activated sludge, constructed wetlands and high rate algal ponds. J. Clean. Prod. 2017, 161, $211-219$. [CrossRef]

6. Molinos-Senante, M.; Gómez, T.; Garrido-Baserba, M.; Caballero, R.; Sala-Garrido, R. Assessing the sustainability of small wastewater treatment systems: A composite indicator approach. Sci. Total Environ. 2014, 497, 607-617. [CrossRef] [PubMed]

7. Marín-Muñiz, J.L. Humedales construidos para el tratamiento de aguas residuales, producción de plantas ornamentales y reuso del agua. Agroproductividad 2017, 10, 90-95. (In Spanish). Available online: http: //revista-agroproductividad.org/index.php/agroproductividad/article/view/1028 (accessed on 5 November 2019).

8. Yang, Y.; Zhao, Y.; Liu, R.; Morgan, D. Global development of various emerged substrates utilized in constructed wetlands. Bioresour. Technol. 2018, 261, 441-452. [CrossRef]

9. Wang, R.; Korboulewsky, N.; Prudent, P.; Domeizel, M.; Rolando, C.; Bonin, G. Feasibility of using an organic substrate in a wetland system treating sewage sludge: Impact of plant species. Bioresour. Technol. 2010, 101, 51-57. [CrossRef]

10. Zhu, W.L.; Cui, L.H.; Ouyang, Y.; Long, C.F.; Tang, X.D. Kinetic adsorption of ammonium nitrogen by substrate materials for constructed wetlands. Pedosphere 2011, 21, 454-463. [CrossRef]

11. Marín-Muñiz, J.L.; García-González, M.C.; Ruelas-Monjardín, L.C.; Moreno-Casasola, P. Influence of different porous media and ornamental vegetation on wastewater pollutant removal in vertical subsurface flow wetland microcosms. Environ. Eng. Sci. 2018, 35, 88-94. [CrossRef] 
12. Marín-Muñiz, J.L. Removal of wastewater pollutant in artificial wetlands implemented in Actopan, Veracruz, Mexico. Rev. Mex. Ing. Química 2016, 15, 553-563. Available online: http://www.redalyc.org/articulo.oa?id= 62046829021 (accessed on 30 July 2019).

13. Dallas, S.; Ho, G. Subsurface flow reedbeds using alternative media for the treatment of domestic greywater in Monteverde, Costa Rica, Central America. Water Sci. Technol. 2005, 51, 119-128. Available online: https://www.ncbi.nlm.nih.gov/pubmed/16104413 (accessed on 5 November 2019). [CrossRef]

14. Shiwei, C.; Zhaoqian, J.; Peng, Y.; Yue, W.; Yin, W. Performance of constructed wetlands with different substrate for the treated effluent form municipal sewage plants. J. Water Reuse Desalin. 2019. (In press) [CrossRef]

15. Zamora, S.; Sandoval, L.; Marín-Muñiz, J.L.; Fernández-Lambert, G.; Hernánez-Orduña, G. Impact of ornamental vegetation type and different substrate layers on pollutant removal in constructed wetland mesocosms treating rural community wastewater. Processes 2019, 11, 531. [CrossRef]

16. Ding, Y.; Luy, T.; Bail, S.; Li, Z.; Ding, H.; You, S.; Xie, Q. Effect of multilayer substrate configuration in horizontal subsurface flow constructed wetlands: Assessment of treatment performance, biofilm development, and solids accumulation. Environ. Sci. Pollut. Res. 2018, 25, 1883-1891. [CrossRef] [PubMed]

17. Bail, S.; Lyu, T.; Ding, Y.; Li, Z.; Wang, D.; You, S.; Xie, Q. Campus sewage treatment in multilayer horizontal subsurface flow constructed wetlands: Nitrogen removal and microbial community distribution. Clean Soil Air Water 2017, 45, 1700254. [CrossRef]

18. APHA-AWWA-WFF. Standard Methods for the Examination of Water and Wastewater; American Public Health Association: Washington, DC, USA, 2005.

19. Liu, X.; Huang, S.; Tang, T.; Liu, X.; Scholz, M. Growth characteristic and nutrient removal capability of plants in subsurface vertical flow constructed wetlands. Ecol. Eng. 2012, 44, 189-198. [CrossRef]

20. Vymazal, J. Removal of nutrients in various types of constructed wetlands. Sci. Total Environ. 2007, 380, 48-65. [CrossRef]

21. Kadlec, R.H.; Reddy, K.R. Temperature effects in treatment wetlands. Water Environ. Res. 2001, 73, 543-557. [CrossRef]

22. Sandoval, L.; Zamora-Castro, S.A.; Vidal-Álvarez, M.; Marín-Muñiz, J.L. Role of Wetland Plants and Use of Ornamental Flowering Plants in Constructed Wetlands for Wastewater Treatment: A Review. Appl. Sci. 2019, 9, 685. [CrossRef]

23. Cárdenas-López, D.; Baptiste, M.P.; Castaño, N. Familia Zingiberaceae Hedychium coronarium. Plantas Exóticas con Alto Potencial de Invasión en Colombia. 2010. (In Spanish). Available online: http://hdl.handle.net/20.500. 11761/32935 (accessed on 25 February 2019).

24. Cordeiro, C.A.M.M.; Costa, T.M. Evaluation of solid residues removed from a mangrove swamp in the São Vicente Estuary, SP, Brazil. Mar. Pollut. Bull. 2010, 60, 1762-1767. [CrossRef]

25. Wang, Q.; Hu, Y.; Xie, H.; Yang, Z. Constructed wetlands: A review on the role of radial oxygen loss in the rhizosphere by macrophytes. Water 2018, 10, 678. [CrossRef]

26. Tian, C.; Wang, C.; Tian, Y.; Wu, X.; Xiao, B. Root oxygen loss and the effects of rhizosphere micro area of two submerged plants. Pol. J. Environ. Stud. 2015, 24, 1795-1802. [CrossRef]

27. CONAGUA. Numeragua. Comisión Nacional del Agua. México. 2018. (In Spanish). Available online: http://sina.conagua.gob.mx/publicaciones/Numeragua_2018.pdf (accessed on 7 August 2019).

28. Russell, D.L. Practical Wastewater Treatment; John Wiley\& Sons: Hoboken, NJ, USA, 2019; Available online: https://books.google.com.mx/books?hl=es\&lr=\&id=F6mMDwAAQBAJ\&oi=fnd\&pg=PR17\& $\mathrm{dq}=+$ in + Mexico, + monitors+water+bodies+have+established+that+an+acceptable+criterion+COD+ discharge+biologically+treated +wastewater+must+not+exceed+40+mg/L+\&ots=fGvreeyPSF\&sig= t74EfHW3bcT7GLhmGNhjA6_BjHs\#v=onepage\&q\&f=false (accessed on 15 June 2019).

29. Abbasi, H.; Xie, J.; Hussain, S.; Lu, X. Nutrient removal in hybrid constructed wetlands: Spatial-seasonal variation and the effect of vegetation. Water Sci. Technol. 2019, 79, 1985-1994. [CrossRef] [PubMed]

30. Zurita, F.; White, J.R. Comparative study of three two-stage hybrid ecological wastewater treatment systems for producing high nutrient reclaimed water for irrigation reuse in developing countries. Water 2014, 6, 213-228. [CrossRef] 
31. Martínez, N.B.; Tejeda, A.; Del Toro, A.; Sánchez, M.P.; Zurita, F. Nitrogen removal in pilot-scale partially saturated vertical wetlands with and without and internal source of carbon. Sci. Total Environ. 2018, 645, 524-532. [CrossRef]

32. USEPA. United States Environmental Protection Agency, Superfund Public Health Evaluation Manual; EPA/5401/1-86/060; USEPA: Washington, DC, USA, 1986.

33. Wang, G.; Gao, J.; Yang, R.; Zhang, J.; Guo, H.; Gao,J. Preparation of sustainable non-combustion filler substrate form waterworks sludge/aluminum slag/gypsum/silica/malfan stone for phosphorous immobilization in constructed wetlands. Water Sci. Technol. 2019, 80, 153-163. [CrossRef]

34. Kizito, S.; Luo, H.; Wu, S.; Ajmal, Z.; Lv, T.; Dong, R. Phosphate recovery form liquid fraction of anaerobic digestate using four slow pyrolyzed biochars: Dynamics of adsorption, desorption and regeneration. J. Environ. Manag. 2017, 201, 260-267. [CrossRef]

35. Hernández, M.E.; Galindo-Zetina, M.; Hernández-Hernández, J.C. Greenhouse gas emissions and pollutant removal in treatment wetlands with ornamental plants under subtropical conditions. Ecol. Eng. 2018, 114, 88-95. [CrossRef]

36. Liang, M.; Zhang, C.; Peng, C.; Lai, Z.; Chen, D.; Chen, Z. Plant growth, community structure, and nutrient removal in monoculture and mixed constructed wetlands. Ecol. Eng. 2011, 37, 309-316. [CrossRef]

37. Karathanasis, A.D.; Potter, C.L.; Coyne, M.S. Vegetation effects on fecal bacteria, BOD, and suspended solid removal in constructed wetlands treating domestic wastewater. Ecol. Eng. 2003, 20, 157-169. [CrossRef]

38. Zhang, L.; Lyu, T.; Zhang, Y.; Button, M.; Arias, C.; Weber, K.; Brix, H.; Carvalho, P. Impacts of design configuration and plants on the functionality of the microbial community of mesocosm-scale constructed wetlands treating ibuprofen. Water Res. 2018, 131, 228-238. [CrossRef]

39. Zhang, Y.; Gao, T.; Kang, S.; Sillanpää. Importance of atmospheric transport for microplastics deposited in remote areas. Environ. Pollut. 2019, 254, 112953. [CrossRef]

(C) 2019 by the authors. Licensee MDPI, Basel, Switzerland. This article is an open access article distributed under the terms and conditions of the Creative Commons Attribution (CC BY) license (http://creativecommons.org/licenses/by/4.0/). 